\title{
PENGARUH PERSEPSI SISWA ATAS MODEL PEMBELAJARAN KOOPERATIF DAN KEMAMPUAN BERPIKIR KRITIS TERHADAP KETERAMPILAN BERBICARA
}

\author{
Nurul Akmaliah, Doni Anggoro Ari Santoso \\ Program Studi Pendidikan Bahasa Inggris, Fakultas Bahasa dan Seni \\ Universitas Indraprasta PGRI \\ akmaliahnurul10@gmail.com;don.okba@gmail.com
}

\begin{abstract}
Abstrak
Penelitian ini bertujuan untuk mengetahui pengaruh persepsi siswa atas model pembelajaran kooperatif dan kemampuan berpikir kritis secara bersama-sama terhadap keterampilan berbicara bahasa Inggris siswa SMK Negeri Depok. Metode yang digunakan dalam penelitian adalah metode survei penjelasan (explanatory survey method) dengan pendekatan kuantatif melalui metode korelasional. Sampel diambil 60 orang siswa atau $33 \%$ dari populasi, teknik pengambilan sampel dilakukan secara acak dengan teknik sampel sistematis. Hasil penelitian: Terdapat pengaruh yang signifikan persepsi siswa atas model pembelajaran kooperatif dan kemampuan berpikir kritis siswa secara bersama-sama terhadap keterampilan berbicara bahasa Inggris. Hal ini dibuktikan dengan Fhitung $=12.832>$ Ftabel $=3.16$, dan sig $=0.000<$ 0.05 . Variabel persepsi siswa atas model pembelajaran kooperatif dan kemampuan berpikir kritis siswa menentukan tingkat keterampilan berbicara bahasa Inggris sebesar $31 \%$.
\end{abstract}

Kata Kunci: Persepsi Siswa atas Model Pembelajaran Kooperatif, Berpikir Kritis, Keterampilan Berbicara

\begin{abstract}
The aim of this study is to find out the effects of student's perception on cooperative learning model and Critical Thinking Skill toward student's speaking skill of Depok's Vocational School. The method used in this research is explanatory survey method by quantitative approach through correlational method. 60 students are taken as a sample or $33 \%$ of population, the samples are taken randomly by systematic sample technique. The result of the research is there is effect of student's perception on cooperative learning model and Critical Thinking Skill toward student's speaking skill of Depok's Vocational School. It is proved by $F_{\text {observed }}=12.832>F_{\text {table }}=3.16$, dan sig $=0.000<0.05$. Student's perception on cooperative learning model and Critical Thinking Skill Variables determined the student's speaking skill of $31 \%$.
\end{abstract}

Key words: student's perception on cooperative learning model, Critical Thinking, speaking skill.

\section{PENDAHULUAN}

Pemerintah dengan berbagai usaha mengadakan perbaikan mutu pendidikan bahasa pada khususnya antara lain penyempurnaan kurikulum. Pengadaaan dan revisi buku pelajaran serta peningkatan kualifikasi guru dari pendidikan diploma ditingkatkan ke pendidikan strata satu. Usaha yang telah dilakukan pemerintah ini belum menampakan hasil yang maksimal sebagaimana masih rendahnya perolehan skor pada tes hasil belajar bahasa yang diberikan kepada siswa. Oleh karena itu, usaha meningkatkan skor pada tes kemampuan berbicara bahasa Inggris yang diberikan kepada siswa harus dilakukan secara menyeluruh. Proses belajar mengajar ini 
merupakan proses timbal balik antara guru dan siswa untuk secara bersama mengusahakan pencapaian tujuan intruksional yang telah disusun oleh guru yang sebelumnya. Oleh karena itu usaha pencapaian skor yang tinggi sebagai wujud hasil belajar siswa bukan hanya tanggung jawab guru semata namun yang paling utama adalah tanggung jawab siswa dalam kesiapannya menerima dan mengembangkan ilmu yang diberikan guru dengan menunjukkan sikap dan motivasi yang positif terhadap bahasa dengan model pembelajaran kooperatif yang baik yang dilandasi oleh kemampuan berpikir kritis yang cukup baik.

Tes pada umumnya hanya mengukur aspek kognitif saja sedangkan aspek afektif dan psikomotorik hampir tidak diperhatikan dalam penilaian tingkat keberhasilan belajar siswa. Tingkah laku sebagai hasil dari proses belajar dipengaruhi oleh banyak faktor, baik faktor yang terdapat dalam diri siswa (internal) atau yang berada di luar diri siswa (ekternal).

Kemampuan berpikir kritis sebagai cara berpikir yang sistematis dan mandiri, yang akan menghasilkan suatu interpretasi, analisis, atau kesimpulan terhadap suatu hal atau permasalahan. Latihan-latihan untuk membiasakan kemampuan berpikitr kritis ini harus disesuaikan dengan umur si anak sendiri. Jangan sampai orang tua memaksakan diri untuk melatih si anak di luar kemampuannya. Kemampuan berpikir kritis akan sangat bermanfaat ketika seseorang dihadapkan pada suatu persoalan yang rumit.

\section{Pengertian Keterampilan Berbicara bahasa Inggris}

Berbicara (speaking) merupakan salah satu faktor yang paling dominan dalam mempelajari suatu bahasa, dimana berbicara (speaking) adalah suatu kegiatan dalam rangka memproduksi ungkapan-ungkapan pikiran dengan suara keras, mengekspresikan arti kata seseorang dalam bentuk padanan atau wacana melalui ucapan perkataan. Dalam aktivitasnya berbicara (speaking) merupakan gabungan dari subsistem, dimana faktor-faktor dan semua sistem tersebut dikombinasikan untuk diimplementasikan kedalam sebuah bahasa yang terbentuk dalam bahasa sehingga dapat dipahami dan pada akhirnya terjadi suatu komunikasi yang jelas. Faktor-faktor yang dimaksud adalah memonitor dan memahami lawan bicara, berpikir tentang kontribusikontribusi tersebut dalam ungkapan bahasa lisan dan efek-efeknya berdasarkan hasil monitornya dan memahami lawan bicara oleh karena itu berbicara (speaking) dipandang sebagai keterampilan terpusat, sehingga dalam mempelajari suatu bahasa asing berbicara (speaking) juga dipandang sebagai keterampilan komunikatif. Dalam mempelajari sebuah bahasa yang paling diperhatikan adalah segi komunikatifnya, karena bahasa identik dengan ucapan atau perkataan, dan segala produksi bahasa lain, karena itu keterampilan merupakan ukuran untuk mempelajari sebuah bahasa.

Dengan melihat penjelasan di atas, jelaslah bahwa banyak hal yang perlu diperhatikan untuk menguasai keterampilan berbicara (speaking skill). Oleh karena itu konteks pembicaraan yang dilakukan oleh dua orang atau lebih harus dipahami satu sama lain agar tercipta suatu pembicaraan yang mengarah pada konteks yang sistematis dan terorganisir berdasarkan kaidahkaidah dalam suatu pembicaraan, sehingga akan menghasilkan sebuah topik pembicaraan yang akurat. Sehingga pada akhirnya dapat memuaskan satu sama lain diantara pelaku pembicara dan memperoleh 
keterampilan berbicara yang merupakan hasil dalam mempelajari sebuah bahasa. keterampilan berbicara menurut Erien KS (1981:51) adalah: "keterampilan mengolah kata dalam merangkaikan sebuah kalimat, kemudian dikembangkan dalam bahasa komunikasi."(GBPP, 1999:75).

Selain itu berbicara juga merupakan kegiatan lisan, hal ini berkaitan dengan bunyi-bunyi bahasa, yang mana dengan seseorang menyampaikan ide/ pikiran melalui katakata. Hal ini diperkuat lagi oleh Tarigan (2003:34) bahwa "berbicara adalah keterampilan mengungkapkan bunyibunyi artikulasi/kata-kata untuk mengekspresikan, menyatakan serta menyampaikan pikiran, gagasan dan perasaan." Hal ini diperjelas lagi oleh Finocchiraro (1999:141) bahwa: "Speaking is complex than listening for addition to knowing the sounds, structure, vocabulary and the lacture subsystem of the language.

Keterampilan berbicara memerlukan komunikatif seperti yang dikemukakan Nababan (2000:172) mengatakan bahwa: keterampilan komunikatif adalah "The knowledge about language fron and the meaning it's from and the ability to use which is whom and to use these from normally." Berdasarkan pendapat di atas, keterampilan berbicara adalah keterampilan untuk melakukan komunikasi antara satu dengan lainnya, dimana keterampilan berbicara adalah suatu keterampilan manusia untuk mengungkapkan tentang segala sesuatu yang terkandung dalam pikirannya lebih jauh.

Satu faktor yang penting agar komunikatif itu nampak adalah unsur yang tidak dapat diterka sebelumnya. (information gap) yaitu siswa tidak dapat mengetahui sebelumnya bagaimana lawan bicara akan memberi tanggapan/reaksi atas apa yang mereka lakukan untuk mengungkapkan pikiran yang bersifat komunikatif tidak berbentuk satu arah,melainkan dua arah. Sedangkan speaking skill adalah keterampilan seseorang dalam mengungkapkan bunyi-bunyi atau katakata untuk mengekspresikan, menyatakan pikiran, gagasan atau perasaan. Apabila seseorang berbicara, apapun bahasanya dan dari mana asalanya, tentu menggerakkan bibir, rahang, serta lidahnya dan bagian-bagian lain dari mulut, hidung, kerongkongan dan sekat rongga dada dengan cara tertentu. Gerakan-gerakan dari organ tubuh inilah yang menghasilkan bunyi dan didengar orang lain. Berbicara adalah bahasa yang "diungkapkan" bukan bahasa yang ditulis. Berbicara merupakan keterampilan bahasa yang lebih komplek dari pada menyimak karena bukan hanya melibatkan suatu (intonasi, tekanan, dan ungkapan) serta kultur dimana bahasa tersebut digunakan sebagai bahasa ibu. "speaking is more a complete skill than listening, for in addition in knowing the sounds, structure, vocabulary and culture ubsystem of the language." Sedangkan menurut kamus Webster (Meriam Webster 2003:197) berbicara adalah "To utter words or articulate sounds with the ordinary voice,to express thoughts, opinions or a feeling orally, to extend greeting..." Dengan demikian makna berbicara itu lebih daripada hanya sekedar pengucapan bunyi-bunyi atau kata-kata, tetapi salah satu cara manusia mengungkapkan diri. Dengan berbicara manusia dapat mengungkapkan pikiran,perasaan maupun gagasan secara lisan. Selain itu manusia adalah makhluk sosial dan manusia dapat terwujud aneka bentuk. Lingkungan terkecil adalah keluarga dan sampai pada lingkungan masyarakat.

Berdasarkan uraian di atas dapat disintesiskan kemampuan berbicara 
bahasa Inggris adalah suatu aktifitas belajar yang berkaitan dengan keterampilan produktif untuk berkomunikasi dengan menggunakan bahasa Inggris yang melibatkan banyak aspek seperti; pelafalan bunyi (pronounciation), keterampilan tata bahasa (grammar), keterampilan diksi, kelancaran (fluency), serta pemahaman (comprehention-ability) dari peserta didik dalam menyerap materi pelajaran Bahasa Inggris yang akhirnya dapat menghasilkan perubahan tingkah laku peserta didik dalam bentuk pemahaman baru dan perubahan tersebut relatif tetap (membekas dalam benak peserta didik)

\section{Pengertian Persepsi atas Model Pembelajaran Kooperatif}

Menurut Richards and Rodgers (2003:192), an approach to teaching that makes maximum use of cooperative activities involving pairs and small groups of learners in the classroom. Menurut Richards and Rodgers dalam pembelajaran kooperatif siswa beraktivitas secara berpasangan atau kelompok sehingga usaha pembelajaran berjalan maksimal. Hal ini sejalan dengan yang dikatakan oleh Olsen and Kagan (1992:28): cooperative learning is a group learning activity organized so that learning is dependent on the socially structured exchanged of information between learners in groups and in which each learner is held accountable for his or her own learning and is motivated to increase the learning of others. Sehingga satu sama lain saling mendukung dalam proses pembelajaran. Tujuan model pembelajaran kooperatif; tujuan pengajar adalah menumbuhkan kemampuan penggunaan bahasa yang pernah dipelajarinya sedangkan tujuan pembelajar adalah memperoleh kemampuan penggunaan bahasa pada konteks dan situasi sebenarnya.
Dalam model pembelajaran kooperatif ada beberapa model yang dikembangkan yang harus diperhatikan yaitu: Konteksnya nyata dan digunakan dalam komunikasi yang sebenarnya, tugasnya mengandung arti dan makna, tugas kegiatan di kelas berupa information gap task, penjelasannya bisa dari hal yang sempit ke luas atau sebaliknya. pengoreksian tidak dilakukan saat kegiatan, karena komunikasinya sesuai keinginan pembicara dan lawan bicara, kesalahan siswa saat berlatih diabaikan, dan diperbaiki saat kegiatan selesai, tidak dijelaskan struktur tatabahasa pola kalimatnya, tetapi dijelaskan penggunaan pola kalimatnya. Kegiatan dengan model pembelajaran kooperatif mempunyai 3 kegiatan yaitu:

1. Information gap; Pembicara dan lawan bicara memiliki informasi yang berbeda. Pembicara mempunyai informasi yang tidak dimiliki lawan bicara. Begitu pula sebaliknya, lawan bicara memiliki informasi yang tidak dimiliki pembicara.

2. Jawaban bebas; ketika berkomunikasi, lawan bicara yang ditanya memiliki pilihan jawaban dan dapat dijawab dengan bebas. Jawaban diputuskan sendiri oleh penjawab, cara menyampaikannya dan lamanya waktu menjawab juga diputuskan sendiri.

3. Feedback (umpan balik); adanya komunikasi dua arah, yaitu adanya respon. Respon didapat pembicara dari lawan bicara. Respon bisa berupa verbal (ucapan) atau non verbal (gerakan dan ekspresi). Jadi apabila lawan bicara tidak menjawab apapun tetapi memberikan respon dengan ekspresi berarti kita telah mendapatkan feedback.

Dalam menerapkan prinsip-prinsip model pembelajaran kooperatif, yaitu 
siswa perlu terlibat dalam proses belajar secara spontan, siswa terlibat secara aktif dalam proses belajar-mengajar. Dalam pendekatan komunikatif, ada beberapa metode yang dapat diterapkan metode simulasi diterapkan dengan aturan sebagai berikut: siswa dibagi atas kelompok kecil. Setiap kelompok paling banyak lima orang, guru menyediakan topik pembicaraan yang akan dibahas oleh setiap kelompok. Metode Team; diterapkan dengan aturan sebagai berikut; penyajian guru, diskusi kelompok siswa, tes/kuis/silang tanya antar kelompok, penguatan dari guru. Penyajian guru mengenai pokok-pokok permasalahan, konsep, kaidah, dan prinsip-prinsip bidang ilmu. Penyajian guru dalam bentuk ceramah dan tanya jawab. Diskusi kelompok dilakukan berdasarkan permasalahan yang disampaikan oleh guru. Setelah itu, tes/kuis dilakukan untuk mengetahui hasil belajar siswa. Terakhir, penguatan guru dilakukan untuk menyakinkan keragu-raguan siswa dan silang pendapat antar kelompok dalam diskusi.

Metode game diterapkan dengan aturan sebagai berikut; identifikasi masalah, pembahasan masalah dalam kelompok, presentasi hasil bahasan kelompok/turnamen, penguatan oleh guru. Dalam identifikasi masalah, siswa ditugaskan membaca sebuah konsep di rumah. Kemudian, konsep itu dipecahkan dalam kelompok. Setelah itu, pemecahan masalah disajikan dalam bentuk presentasi guru dan beberapa siswa menjadi juri. Metode kaji pengalaman diterapkan dengan aturan sebagai berikut; siswa diundang ke depan kelas diminta mengemukakan pendapatnya mengenai topik yang telah disediakan, guru memberanikan siswa agar ia dapat mengemukakan pendapat, guru dapat memperbaiki kesalahan penggunaan bahasa yang dilakukan siswa, para siswa mencatat kesalahan dan perbaikan yang dibahas bersamasama. Penulis menyadari bahwa keempat metode dalam model pembelajaran kooperatif yang ditawarkan di atas kadang-kadang tidak cocok untuk pokok bahasan tertentu. Memang di satu sisi, model pembelajaran kooperatif ini memiliki beberapa kelemahan. Kelemahankelemahan itu mungkin dari sisi siswa, sisi penyusunan bahan, dan dari sisi pengajar sendiri. Model pembelajaran kooperatif merupakan pendekatan yang berlandaskan pemikiran bahwa kemampuan menggunakan bahasa dalam berkomunikasi merupakan tujuan yang harus dicapai dalam pembelajaran bahasa Inggris disekolah-sekolah tingkat dasar maupun atas.

Dalam konsep model pembelajaran kooperatif terdapat konsep kompetensi yang membedakan komponen bahasa menjadi dua bagian. Kompetensi itu adalah keterkaitan dan interelasi antara kompetensi gramatikal atau pengetahuan kaidah-kaidah bahasa dengan kompetensi sosiolinguistik atau aturan-aturan tentang penggunaan bahasa yang sesuai dengan kultur masyarakat. Kompetensi hendaknya dibedakan dengan performansi, karena performansi komunikatif mengacu pada realisasi kompetensi kebahasaan beserta interaksinya dalam pemroduksian secara aktual dengan pemahaman terhadap tuturan-tuturan. Oleh sebab itu, seseorang yang dikatakan memiliki kompetensi dan performansi berbahasa yang baik hendaknya mampu berkomunikasi dengan menggunakan bahasa yang dipelajarinya, baik dalam pemroduksian (berbicara dan menulis/mengarang) maupun dalam pemahaman (membaca dan mendengarkan). Brumfit dan Finocchiaro mengungkapkan model pembelajaran kooperatif adalah (1) makna merupakan yang terpenting, (2) 
percakapan harus berpusat di sekitar fungsi komunikatif dan tidak dihafalkan secara normal, (3) kontekstualisasi merupakan premis pertama, (4) belajar bahasa berarti belajar berkomunikasi, (5) komunikasi efektif dianjurkan, (6) drill diperbolehkan, tetapi tidak memberatkan, (7) ucapan yang dapat dipahami diutamakan, (8) setiap alat bantu peserta didik diterima dengan baik, (9) segala upaya untuk berkomunikasi dapat didorong sejak awal, (10) penggunaan bahasa secara bijaksana dapat diterima bila memang layak, (11) terjemahan digunakan jika diperlukan peserta didik, (12) membaca dan menulis dapat dimulai sejak awal, (13) sistem bahasa dipelajari melalui kegiatan berkomunikasi, (14) belajar secara kooperatif merupakan tujuan, (15) variasi linguistic merupakan konsep inti dalam materi dan metodologi, (16) urutan ditentukan berdasarkan pertimbangan isi, fungsi, atau makna untuk memperkuat minat belajar, (17) guru mendorong peserta didik agar dapat bekerja sama dengan menggunakan bahasa itu, (18) bahasa diciptakan oleh peserta didik melalui mencoba dan mencoba, (19) kefasihan dan bahasa yang merupakan tujuan utama, ketepatan dinilai dalam konteks bukan dalam keabstrakan, (20) peserta didik diharapkan berinteraksi dengan orang lain melalui kelompok atau pasangan, lisan dan tulis, (21) guru tidak bisa meramal bahasa apa yang akan digunakan peserta didiknya, dan (22) motivasi intrinsik akan timbul melalui minat terhadap hal-hal yang dikomunikasikan.

\section{Pengertian Kemampuan Berpikir Kritis}

Berpikir kritis merupakan suatu proses mental yang didahului oleh penginderaan yang diteruskan ke pusat susunan syaraf sehingga individu menyadari apa yang dikatakan, apa yang dilihat dan apa yang didengar. Stimulus yang dinderakan oleh indidividu kemudian dinterprestasikan, inilah yang disebut berpikir. Berpikir kritis ditujukan pada makna seseorang, lingkungan dan informasinya. (Chaplin, 2001:25) mengatakan bahwa "berpikir kritis merupakan kesadaran intuitif mengenai kebenaran langsung atau keyakinan yang serta merta mengenai sesuatu". Motivasi merupakan alat bagi seseorang untuk mengajak siswa agar berpikir mengenai sesuatu, sehingga tujuan organisasi dicapai dengan baik. Berpikir juga biasa didefinisikan pada proses yang menentukan intensitas, arah dan individu dalam upaya mencapai sasaran, meski berpikir terkait dengan usaha. Berpikir yang menyangkut aktifitas dan perilaku manusia dan merupakan elemen vital didalam manajemen diri dan perubahan dalam perilaku manusia.

Upaya membangkitkan pola berpikir pada seseorang bukan hanya melalui penghargaan atas keahlian dan penempatan yang layak sesuai kemampuannya yang sangat besar dalam dunia ilmu. Berpikir merupakan serangkaian sikap dan nilai yang mempengaruhi individu untuk mecapai hal-hal yang specific sesuai dengan tujuan individu (Robbin, 2000,123). Menurut Maslow setiap individu memiliki kebutuhan dalam melakukan aktifitas untuk mencapai tujuan individu. Berpikir berhubungan dengan arah perilaku, kekuatan respon dan ketahanan perilaku. Pandangan lain menyarankan bahwa analisis dan berpikir harus memusatkan perhatian pada faktorfaktor yang mendorong dan mengarahkan seseorang untuk suatu tujuan. Pada dasarnya berhubungan erat dengan bagaimana perilaku dimulai dikuatkan, didukung perilaku, kekuatan respon dan ketahanan perilaku. Pandangan lain 
menyarankan bahwa analisis berpikir kritis harus memusatkan perhatian pada faktor-faktor yang mendorong dan mengarahkan kegiatan seseorang. Berpikir pada dasarnya berhubungan erat dengan bagaimana perilaku itu dimulai dan diarahkan. Pada dasarnya, berakar pada kebutuhan yang disusun berdasarkan prioritas kekuatan kebutuhan yang dimiliki manusia, ada dua cara yang dapat menimbulkan pemikiran. Berpikir timbul karena dibuat dan timbul dari dalam dirinya yaitu faktor-faktor yang mendukung seseorang untuk berbuat sesuatu. Berpikir dalam diri seorang adalah pendorong untuk melakukan sesuatu motivasi berasal dari seseorang untuk bergerak melakukan sesuatu atau mengarahkan seseorang maupun kelompok untuk mencapai tujuan tertentu. Berpikir menurut Gagne (1973:45) adalah: Suatu keadaan diri seseorang yang mendorong bersangkutan untuk melakukan aktifitas tertentu guna mencapai tujuan. Perilaku yang disebabkan oleh pemikiran ialah perilaku yang mengarah pada tujuan tertentu dan berhubungan erat bagaimana itu dimulai, dikuatkan didukung diarahkan atau dihentikan dari reaksi subjektif yang timbul.

\section{METODE PENELITIAN}

Penelitian ini dilaksanakan di Sekolah Menengah Kejuruan Negeri Depok sesuai dengan kesepakatan peneliti dengan kepala sekolah yang menjadi obyek penelitian, disepakati penelitian dilaksanakan saat semester ganjil berlangsung, dan data hasil belajar didapat dari hasil ulangan-ulangan dan tes keterampilan berbicara. Metode yang digunakan dalam penelitian adalah metode survey penjelasan (explanatory survey method) dengan pendekatan kuantatif melalui metode korelasional.
Menurut Kerlinger (1973) yang dikutip Sugiyono, (2004:7) "penelitian survei adalah penelitian yang dilakukan pada populasi besar atau kecil, sehingga ditemukan kejadian-kejadian relatif, distribusi, dan hubungan antar variabel sosiologis maupun psikologis". Pada metode korelasional ini pengaruh antara variabel akan diteliti dan dijelaskan, yaitu akan menguji besarnya pengaruh yang ditunjukkan koefisien korelasi antar variable persepsi atas model pembelajaran kooperatif $\left(\mathrm{X}_{1}\right)$, kemampuan berpikir kritis $\left(\mathrm{X}_{2}\right)$ terhadap keterampilan berbicara bahasa Inggris (Y). Populasi target dalam penelitian ini adalah semua siswa Sekolah Menengah Kejuruan yang mendapatkan pelajaran bahasa Inggris, sedangkan populasi terjangkau adalah siswa kelas XII di Sekolah Menengah Kejuruan jurusan Akomodasi Perhotelan di Depok. Penentuan sampel diawali dengan pengelompokan Sekolah menengah kejuruan swasta menurut wilayah kecamatan yang diwakili atas tiga tempat selanjutnya dari masing-masing wilayah diwakili oleh satu sekolah. Oleh karena itu, perbandingan banyaknya murid kelas XII dari ketiga sekolah adalah tidak terlalu berbeda jauh, maka ditetapkan 60 siswa dari setiap sekolah sehingga seluruhnya berjumlah 180 orang. Sampel diambil 60 orang siswa atau $33 \%$ dari populasi, teknik pengambilan sampel dilakukan secara acak dengan teknik sampel sistematis.

\section{HASIL DAN PEMBAHASAN}

Penelitian ini untuk mengetahui pengaruh tingkat persepsi siswa atas model pembelajaran kooperatif dan kemampuan berpikir kritis siswa secara bersama-sama terhadap keterampilan berbicara bahasa Inggris. Dari deskripsi data setelah diperoleh koefisien korelasi sebesar 0.557 dan koefisien determinasi 
0.31, setelah dilakukan pengujian dengan program SPSS 16.0 terbukti bahwa koefisien korelasi tersebut signifikan. Hal ini berarti bahwa terdapat pengaruh variabel bebas $\mathrm{X}_{1}$ (persepsi siswa atas model pembelajaran kooperatif) dan $\mathrm{X}_{2}$ (kemampuan berpikir kritis siswa) secara bersama-sama terhadap variabel terikat Y (keterampilan berbicara bahasa Inggris).

Dari analisa regresi diperoleh persamaan garis regresi $\breve{Y}=29.906+$ $0.309 \mathrm{X}_{1}+0.209 \mathrm{X}_{2}$. nilai konstanta 29.906 menunjukan bahwa dengan tingkat persepsi siswa atas model pembelajaran kooperatif dan kemampuan berpikir kritis siswa paling rendah, sulit bagi siswa untuk meningkatkan keterampilan berbicara bahasa Inggris. Sedangkan nilai koefisien regresi sebesar 0.309 dan 0.209 menunjukan bahwa terdapat pengaruh positif variabel bebas $\mathrm{X}_{1}$ (persepsi siswa atas model pembelajaran kooperatif ) dan $\mathrm{X}_{2}$ (kemampuan berpikir kritis siswa) secara bersama-sama terhadap variabel bebas $\mathrm{Y}$ (Keterampilan berbicara Bahasa Inggris). Angka koefisien regresi tersebut juga menunjukan bahwa setiap ada kenaikan satu nilai tingkat persepsi siswa atas model pembelajaran kooperatif maka akan terdapat kenaikan keterampilan berbicara bahasa Inggris sebesar 0.309, dan setiap ada kenaikan satu nilai kemampuan berpikir kritis siswa maka akan terdapat kenaikan keterampilan berbicara bahasa Inggris sebesar 0.209.

Setelah dilakukan pengujian linearitas garis regresi dengan menggunakan SPSS 17.0 diperoleh bahwa garis regresi tersebut linear. Dari pengujian signifikansi koefisien regresi yang juga dilakukan dengan program SPSS 16.0 diperoleh bahwa koefisien regresi tersebut signifikan, yang berarti benar bahwa terdapat pengaruh yang positiv variabel bebas $\mathrm{X}_{1}$ (persepsi atas model pembelajaran kooperatif) dan $\mathrm{X}_{2}$ (kemampuan berpikir kritis siswa) secara bersama-sama terhadap variabel terikat Y (keterampilan berbicara bahasa Inggris).

Kemampuan berbicara bahasa Inggris adalah suatu aktifitas belajar yang berkaitan dengan keterampilan produktif untuk berkomunikasi dengan menggunakan bahasa inggris yang melibatkan banyak aspek seperti; pelafalan bunyi (pronounciation), keterampilan tata bahasa (grammar), keterampilan diksi, kelancaran (fluency), serta pemahaman (comprehentionability) dari peserta didik dalam menyerap materi pelajaran Bahasa Inggris yang akhirnya dapat menghasilkan perubahan tingkah laku peserta didik dalam bentuk pemahaman baru dan perubahan tersebut relatif tetap (membekas dalam benak peserta didik). Sedangkan Persepsi atas pembelajaran kooperatif adalah persepsi siswa atas pendekatan pembelajaran kooperatif (student oriented) atau metode yang ditempuh siswa dalam upaya untuk memahami materi bahasa Inggris. Metode pembelajaran ini haruslah sesuai dengan karakteristik bahasa Inggris bersifat abstrak dan deduktif. Selanjutnya kemampuan berpikir kritis adalah kemampuan siswa dalam memahami dan memberi makna terhadap informasi yang diterimanya menyangkut bahasa Inggris, konsep yang mempengaruhi berpikir siswa terhadap bahasa Inggris adalah : (a) pengalaman yang pernah dalami (b) kebutuhan pada bahasa Inggris (c) harapan (d) minat.

Dari uraian teoritis di atas maka bisa diasumsikan bahwa semakin baik persepsi atas model pembelajaran kooperatif maka semakin tinggi pula kemampuan untuk bisa berbicara bahadsa Inggris. Dan begitu pula semakin tinggi kemampuan berpikir 
kritis siswa dalam belajar bahasa Inggris maka semakin tinggi pula keterampilan berbicara dalam bahasa Inggris.

Dari informasi kuantitatif dan teoritis tersebut peneliti berkesimpulan bahwa persepsi siswa atas model pembelajaran kooperatif dan kemampuan berpikir kritis siswa berpengaruh signifikan secara bersamasama terhadap keterampilan berbicara bahasa Inggris.

\section{SIMPULAN}

Setelah peneliti mengadakan penelitian tentang pengaruh dari persepsi siswa atas model pembelajaran kooperatif dan kemampuan berpikir kritis siswa terhadap keterampilan berbicara bahasa Inggris di SMKN Depok. Maka hendaknya, pihak Sekolah-sekolah ini (SMKN Depok) harus terus berupaya untuk meningkatkan persepsi siswa atas model pembelajaran kooperatif. Karena persepsi siswa atas model pembelajaran kooperatif mempunyai pengaruh yang positif dan signifikan terhadap keterampilan berbicara bahasa Inggris. Disamping itu kontribusi persepsi siswa atas model pembelajaran kooperatif terhadap keterampilan berbicara bahasa Inggris cukup besar. Guru yang terlibat dalam proses belajar mengajar di SMKN Depok harus mampu menjelaskan atau menerangkan tentang model pembelajaran kooperatif seditail mungkin sehingga siswa-siswa mengerti bagaimana cara bertanya dan menjawab pertanyaan dalam bahasa Inggris. Disamping itu guru di sekolah-sekolah ini harus mampu memberikan kemampuan berpikir kritis atau dorongan kepada siswa-siswanya dalam meningkatkan kualitas diri mereka. Karena kemampuan berpikir kritis atau dorongan juga memberikan kontribusi yang cukup besar terhadap keterampilan berbicara bahasa Inggris.

\section{DAFTAR PUSTAKA}

Chaplin, J.P. (1999). Kamus Lengkap Psikologi. (Fifth edition). Jakarta: PT. Rajagrafindo Persada.

Departemen Pendidikan dan Kebudayaan, (1999) Kurikulum 2004 GBPP SMA, Jakarta.

Erien KS. (2002) English for SMK : New Ways to Learn a Foreign Language. Angkasa Bandung.

Gagne, R. M. and Leslie, B. (2004). Principles of Instructional Design. New York: Holt, Rinehart And Winston.

Kerlinger, F. N. (1996) Azas azas Penelitian Behavioral, alih bahasa LK Simatupang, Gajah Mada'Universty Perss, Jogjakarta

Finocchiro, M.\& C. Brumfit. (1983) The Functional Nasional Approach: From Theory to Practice. New York: Oxford University Press.

Nababan, S. U, Subyakto. (1983). Metodologi Pengajaran. Jakarta: Gramedia.

Olsen, R and S. Kagan. (1992). Cooperative Language Learning: A Teacher's Resource Book. New York: Prentice Hall

Richards, J. C. and Theodore S. R. (2003). Approaches and Methods in Language Teaching. Cambridge University Press

Robbins, P. S. (2003). Perilaku Organisasi. Jakarta: Gramedia. 
Sugiyono. (2003). Statistika Untuk

Penelitian. Bandung CV

Alfabeta

Tarigan, H.G. (2008). Membaca Sebagian Suatu Ketrampilan Berbahasa. Bandung: Angkasa.
The Indonesia Big Dictionary or KKBI, (2003).

Merriam, W. (2002) Webster.s New World College Dictionary, 4th $E d$. Cleveland: Wiley publishing Inc. 